\title{
Comparison of the homeostasis model assessment and quantitative insulin sensitivity check index with data from forearm metabolic studies for the in vivo assessment of insulin sensitivity
}

M.C. Foss-Freitas and M.C. Foss

\author{
Divisão de Endocrinologia e Metabologia, Departamento de Clínica Médica, \\ Faculdade de Medicina de Ribeirão Preto, Universidade de São Paulo, \\ Ribeirão Preto, SP, Brasil
}

\begin{abstract}
Correspondence
M.C. Foss

Departamento de Clínica Médica

FMRP, USP

Av. Bandeirantes, 3900

14049-900 Ribeirão Preto, SP

Fax: +55-16-633-6695

E-mail: mcfoss@fmrp.usp.br

Research supported by the

University Hospital, Faculdade de

Medicina de Ribeirão Preto, USP,

FAEPA and CAPES.
\end{abstract}

Publication supported by FAPESP.

Received May 29, 2003

Accepted March 2, 2004

\section{Abstract}

The present study was designed to compare the homeostasis model assessment (HOMA) and quantitative insulin sensitivity check index (QUICKI) with data from forearm metabolic studies of healthy individuals and of subjects in various pathological states. Fifty-five healthy individuals and 112 patients in various pathological states, including type 2 diabetes mellitus, essential hypertension and others, were studied after an overnight fast and for $3 \mathrm{~h}$ after ingestion of $75 \mathrm{~g}$ of glucose, by HOMA, QUICKI and the forearm technique to estimate muscle uptake of glucose combined with indirect calorimetry (oxidative and non-oxidative glucose metabolism). The patients showed increased HOMA (1.88 \pm 0.14 vs $1.13 \pm 0.10 \mathrm{pmol} / \mathrm{l} \mathrm{x} \mathrm{mmol} / \mathrm{l})$ and insulin/glucose (I/G) index $(1.058 .9 \pm 340.9$ vs $518.6 \pm 70.7 \mathrm{pmol} / 1 \mathrm{x}$ $\left.(\mathrm{mg} / 100 \mathrm{ml} \text { forearm })^{-1}\right)$, and decreased QUICKI $(0.36 \pm 0.004$ vs 0.39 $\left.\pm 0.006(\mu \mathrm{U} / \mathrm{ml}+\mathrm{mg} / \mathrm{dl})^{-1}\right)$ compared with the healthy individuals. Analysis of the data for the group as a whole (patients and healthy individuals) showed that the estimate of insulin resistance by HOMA was correlated with data obtained in the forearm metabolic studies (glucose uptake: $\mathrm{r}=-0.16, \mathrm{P}=0.04$; non-oxidative glucose metabolism: $\mathrm{r}=-0.20 . \mathrm{P}=0.01$, and $\mathrm{I} / \mathrm{G}$ index: $\mathrm{r}=0.17, \mathrm{P}=0.03$ ). The comparison of QUICKI with data of the forearm metabolic studies showed significant correlation between QUICKI and non-oxidative glucose metabolism $(\mathrm{r}=0.17, \mathrm{P}=0.03)$ or $\mathrm{I} / \mathrm{G}$ index $(\mathrm{r}=-0.37, \mathrm{P}<$ 0.0001). The HOMA and QUICKI are good estimates of insulin sensitivity as data derived from forearm metabolic studies involving direct measurements of insulin action on muscle glucose metabolism.

\section{Introduction}

The control of body glucose homeostasis is mainly due to two closely related physiological mechanisms, i.e., the capacity of the
Key words

- Homeostasis model assessment

- Quantitative insulin sensitivity check index

- Forearm metabolic study

- Insulin sensitivity pancreas to secrete insulin and the biological action of this hormone on insulin-sensitive tissues, especially liver, muscle and adipose tissue (1). It is well known that in various human pathological states such as type 2 
diabetes mellitus, glucose intolerance, obesity, polycystic ovary syndrome, essential hypertension, metabolic syndrome and, more recently, atherosclerosis, insulin resistance (IR) is frequently an associated condition or is considered to be a predictor or pathogenetic factor $(2,3)$. There is also much evidence that defects in insulin secretion occur in these pathological states (4).

Therefore, it is important to have methods to estimate insulin secretion and sensitivity in the human body (5). Previous studies have shown that the most adequate methods to evaluate insulin secretion and its defects are the hyperglycemic clamp and the intravenous glucose tolerance test (6-8). The euglycemic hyperinsulinemic clamp technique is the reference and best method for quantifying insulin sensitivity or resistance in vivo because it directly measures the effects of insulin on glucose utilization under steady state conditions (6). In contrast, the forearm technique to estimate muscle glucose metabolism combined or not with indirect calorimetry directly analyzes the biological action of insulin on a metabolically active tissue, the muscle, and represents a good method to evaluate insulin sensitivity or resistance (9-16). However, these methods are not easily applied in large-scale or routine clinical investigations because they are laborious and expensive. Thus, several alternative and simpler methods have been recently proposed. These include the homeostatic model assessment (HOMA) (17, 18) and the quantitative insulin sensitivity check index (QUICKI) (19-21).

On the basis of these considerations, the objective of the present study was to compare the HOMA and QUICKI with data from forearm metabolic studies (muscle glucose uptake, oxidative and non-oxidative glucose metabolism and insulin/glucose (I/G) index) of healthy individuals and subjects in various pathological states, including type 2 diabetes mellitus, essential hypertension and others.

\section{Subjects and Methods}

The study was conducted on 55 healthy individuals and 112 patients in various pathological states, including type 2 diabetes mellitus $(\mathrm{N}=20)$, essential hypertension $(\mathrm{N}=$ $9)$, acanthosis nigricans $(\mathrm{N}=7)$, acromegaly $(\mathrm{N}=12)$, hyperthyroidism $(\mathrm{N}=11)$, congenital adrenal hyperplasia $(\mathrm{N}=8)$, hyperprolactinemia $(\mathrm{N}=8)$, polycystic ovary syndrome $(\mathrm{N}=16)$, chronic renal failure $(\mathrm{N}=$ $11)$, and psoriasis $(\mathrm{N}=10)$, whose characteristics of sex, age and body mass index (BMI) are presented in Table 1. All subjects were asked to consume a diet containing a minimum of $200 \mathrm{~g}$ of carbohydrate for at least 3 days before the study. The protocol was approved by the Ethics Committee of the University Hospital, School of Medicine of Ribeirão Preto, USP, Brazil. Before giving their consent to participate, the volunteers were carefully informed of the nature, purpose and possible risks of the study. No side effects were observed in any of the patients or volunteers.

After a 12- to 14-h fast, the studies were initiated in the morning with the subjects resting in bed in the supine position at the Endocrine and Metabolism Unit of the University Hospital-FMRPUSP. The brachial artery in the left arm and a right antecubital deep vein were cannulated (10). After an equilibration period of 30-60 min, forearm blood flow was determined by capacitance plethysmography (22), and arterial and venous blood samples were drawn simultaneously to determine plasma glucose (23), total blood $\mathrm{CO}_{2}$ and $\mathrm{O}_{2}(24)$, and serum insulin (25). After this procedure under basal conditions, the subjects ingested $75 \mathrm{~g}$ of glucose dissolved in $300 \mathrm{ml}$ flavored water, additional blood samples were collected and forearm blood flow determinations were made at 30, 60, 120 and 180 min after glucose ingestion.

The amount of substrate taken up or released by the forearm within a determined 
period of time $(\mathrm{Q})$ was calculated using the following equation: $\mathrm{Q}=\mathrm{F}(\mathrm{A}-\mathrm{V})$, where $\mathrm{F}$ is the forearm blood flow and $\mathrm{A}$ and $\mathrm{V}$ are the arterial and venous concentrations of the substrate, respectively. Blood flow and the arteriovenous difference of glucose in whole blood were used to determine the forearm glucose uptake rate. The whole blood glucose concentration was calculated from the plasma glucose level by the formula: whole blood glucose concentration = plasma glucose concentration $\mathrm{x}$ (1-0.3 hematocrit) (26). The relationships between the arteriovenous differences in $\mathrm{CO}_{2}$ and $\mathrm{O}_{2}$ were used to determine the respiratory quotient. The Lusk tables were then used to obtain the carbohydrate and lipid oxidation rates (27). The amount of glucose taken up or oxidized during the $3 \mathrm{~h}$ of the experiment was estimated by the determination of the areas under the curves of the rates of glucose uptake and glucose oxidation, respectively. Non-oxidative glucose metabolism was calculated as the difference between glucose uptake and glucose oxidation. The I/G index was calculated as the ratio of insulin response (area under the curve of serum insulin-pmol/1) to the forearm glucose uptake $(\mathrm{mg} / 100 \mathrm{ml}$ forearm) during the $3 \mathrm{~h}$ of the study.

Using the fasting serum levels of glucose and insulin, the HOMA estimate of IR was determined by the following formula: $\mathrm{IR}=$ insulin $(\mathrm{pmol} / \mathrm{l}) \times$ glycemia $(\mathrm{mmol} / \mathrm{l}) / 135$ (28) and the QUICKI index was calculated by the formula: $1 /[\log$ insulin $(\mu \mathrm{U} / \mathrm{ml})+\log$ glucose (mg/dl)] (19).

Results are reported as means \pm SEM. Data were analyzed statistically by the Wilcoxon-Mann-Whitney test (29) or Student $t$ test (29) and correlations were assessed by a non-parametric test (Spearman) (29). P < 0.05 was considered to indicate statistical significance.

\section{Results}

Mean BMI values did not differ significantly between the group of healthy subjects and the group of patients in various pathological states, while the patients showed greater mean age values than the group of healthy subjects $(\mathrm{P}<0.05$; Table 1$)$. The patients showed higher values of HOMA-IR estimates and $\mathrm{I} / \mathrm{G}$ index than the values of healthy individuals. As expected, the patients revealed decreased QUICKI values when compared with normal controls (Table 1). There was no difference in the amounts of glucose taken up or oxidized or utilized by non-oxidative pathways during the $3 \mathrm{~h}$ of the forearm study between the normal and patient groups.

Table 1. Comparison of homeostasis model assessment (HOMA) and quantitative insulin sensitivity check index (QUICKI) with data from forearm metabolic studies for the assessment of in vivo insulin sensitivity.

\begin{tabular}{lccc}
\hline & Normal subjects & Patients & All subjects \\
\hline Sex & 30M:25F & $39 \mathrm{M}: 73 \mathrm{~F}$ & $69 \mathrm{M}: 98 \mathrm{~F}$ \\
Age (years) & $28.8 \pm 1.3$ & $35.5 \pm 1.1$ & $33.2 \pm 0.9$ \\
BMI (kg/m $\left.{ }^{2}\right)$ & $24.6 \pm 1.2$ & $23.5 \pm 0.3$ & $23.8 \pm 0.4$ \\
HOMA-IR $(\mathrm{pmol} / \mathrm{l} \mathrm{mmol} / \mathrm{l})$ & $1.13 \pm 0.10$ & $1.88 \pm 0.14^{*}$ & $1.60 \pm 0.10$ \\
QUICKI $\left((\mu \mathrm{U} / \mathrm{ml}+\mathrm{mg} / \mathrm{dll})^{-1}\right)$ & $0.39 \pm 0.006$ & $0.36 \pm 0.004^{*}$ & $0.37 \pm 0.003$ \\
I/G index $\left(\mathrm{pmol} / \mathrm{l} \times(\mathrm{mg} / 100 \mathrm{ml} \text { forearm) })^{-1}\right)$ & $518.6 \pm 70.7$ & $1058.9 \pm 340.9^{*}$ & $882.1 \pm 237.3$ \\
Glucose uptake $(\mathrm{mg} / 100 \mathrm{ml}$ forearm) & $103.3 \pm 6.9$ & $102.1 \pm 5.9$ & $102.5 \pm 4.7$ \\
Glucose oxidation $(\mathrm{mg} / 100 \mathrm{ml}$ forearm) & $24.2 \pm 1.7$ & $28.9 \pm 2.3$ & $27.3 \pm 1.7$ \\
Non-oxidative metabolism (mg/100 $\mathrm{ml}$ forearm) & $76.8 \pm 6.6$ & $75.8 \pm 4.5$ & $76.2 \pm 4.1$ \\
\hline
\end{tabular}

Data are reported as means $\pm \mathrm{SEM} . \mathrm{BMI}=$ body mass index; $\mathrm{M}=$ male; $\mathrm{F}=$ female; $\mathrm{I} / \mathrm{G}=$ insulin/glucose index; IR = insulin resistance.

${ }^{*} \mathrm{P}<0.05$ compared to normal subjects (Wilcoxon-Mann-Whitney test). 

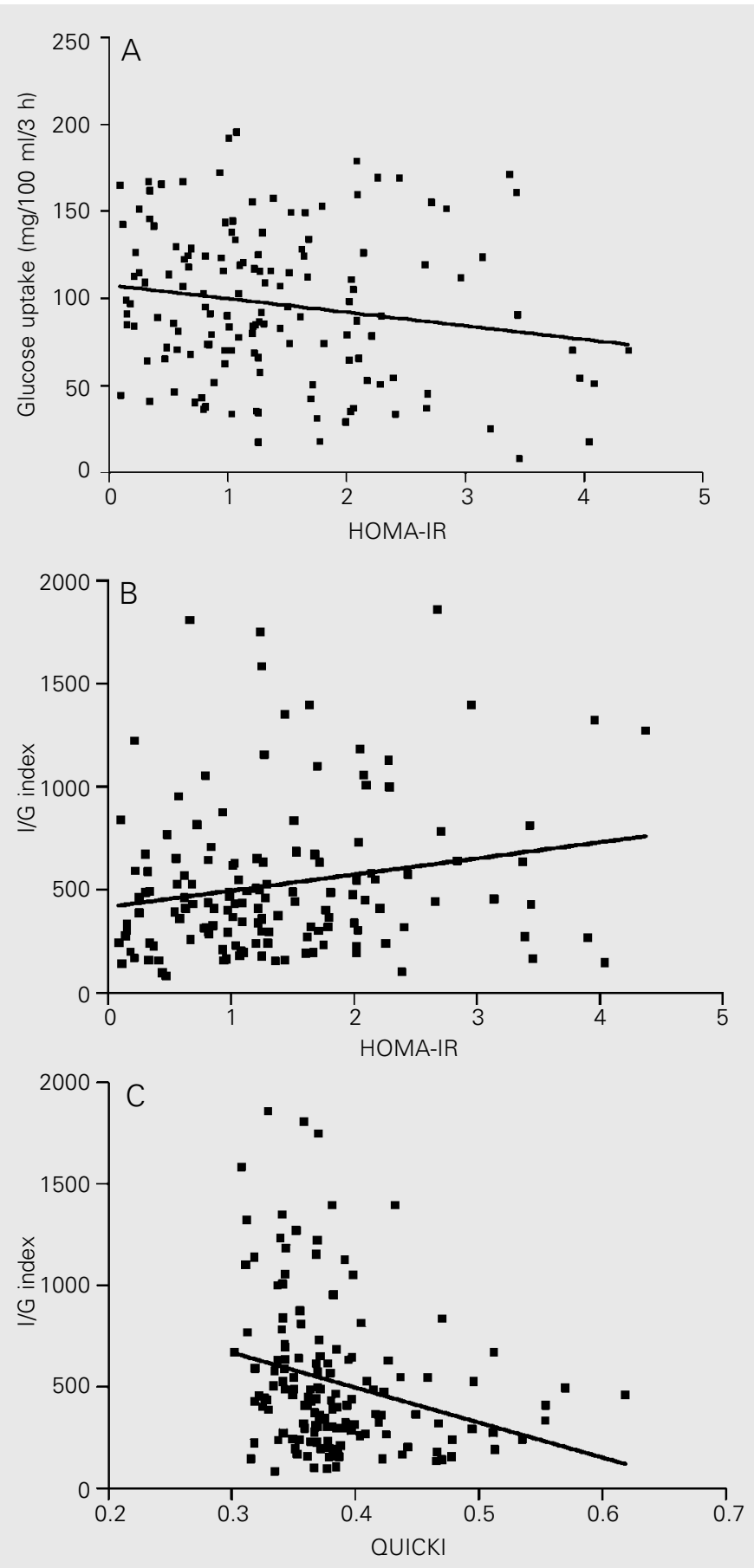

Figure 1. Comparison of homeostasis model assessment (HOMA) and quantitative insulin sensitivity check index (QUICKI) with data from forearm metabolic studies for the assessment of in vivo insulin sensitivity. A, Glucose uptake vs HOMA-IR. Data are for 167 patients and healthy individuals $(r=$ $-0.16, P=0.04$; Spearman correlation test). $B$, Insulin/glucose (I/G) index vs HOMA-IR. Data are for 167 patients and healthy individuals $(r=0.17, P=$ 0.03; Spearman correlation test). C, I/G index vs QUICKI. Data are for 167 patients and healthy individuals $(r=-0.37, P<0.0001$; Spearman correlation test). IR = insulin resistance.
Analysis of the data for the group as a whole (normal subjects and patients) revealed a statistically significant correlation between the estimates of IR by HOMA and the data of the forearm metabolism studies (glucose uptake: $\mathrm{r}=-0.16, \mathrm{P}=0.04$ (Figure $1 \mathrm{~A}$ ), nonoxidative glucose metabolism: $\mathrm{r}=-0.20, \mathrm{P}=$ 0.01 and $\mathrm{I} / \mathrm{G}$ index: $\mathrm{r}=0.17, \mathrm{P}=0.03$ (Figure $1 B)$. The comparison of QUICKI values with data obtained in the forearm metabolic studies showed a significant correlation between QUICKI and non-oxidative glucose metabo$\operatorname{lism}(\mathrm{r}=0.17, \mathrm{P}=0.03)$ and QUICKI and $\mathrm{I} /$ $\mathrm{G}$ index $(\mathrm{r}=-0.37, \mathrm{P}<0.0001$; Figure $1 \mathrm{C})$.

\section{Discussion}

Because of the frequent association of IR as a predictor or pathogenic factor of various human pathological states such as type 2 diabetes mellitus, glucose intolerance, obesity, essential hypertension, polycystic ovarian syndrome, atherosclerosis, and metabolic syndrome, it is important to have methods to estimate insulin sensitivity in the human body (5). The euglycemic hyperinsulinemic clamp technique is the reference method for the quantification of insulin sensitivity or resistance in vivo in the whole body (6), while the forearm technique used to estimate muscle glucose metabolism directly analyzes the biological action of insulin on a metabolically active tissue, the muscle (30). However, since these methods are not easily applied in largescale or routine clinical investigations, several simpler methods have been recently proposed, such as HOMA and QUICKI estimates $(17,19)$.

In the present study, for the first time in the literature, we compared data from forearm metabolic studies of healthy individuals and subjects in various pathological states involving different alterations in insulin sensitivity, with estimates obtained by the HOMA and QUICKI methods. We observed that in the whole group of subjects (normal and patients) the parameters of the forearm 
study, particularly the $\mathrm{I} / \mathrm{G}$ index and the nonoxidative glucose metabolism, were significantly correlated with the HOMA and QUICKI estimates of IR and sensitivity, respectively. The correlation was statistically significant but weak. The I/G index, obtained during the forearm studies as the ratio of the area under the curve of serum insulin concentrations and the area under the curve of muscle glucose uptake, increased when more insulin was necessary to establish a determined rate of glucose entry into the muscle cell. Then the I/G index directly reflects the degree of IR in muscle tissue, and therefore its correlation with HOMA-IR is significant and positive while the correlation with QUICKI is significant and negative. The rate of muscle glucose uptake and even more the non-oxidative metabolism of glucose inside the muscle cell are metabolic processes directly sensitive to insulin. As expected, the amount of glucose utilized during the forearm studies by the non-oxidative pathway inside the muscle cells of the subjects correlated positively with the QUICKI value and inversely correlated with the HOMA estimate. It is important to emphasize that the statistical significance of the correlations was higher when we compared the HOMA and QUICKI estimates with the $\mathrm{I} / \mathrm{G}$ index, that better reflects the degree of IR in muscle tissue.

The HOMA estimates of IR and B-cell deficiency are derived from a mathematical model of the glucose-insulin interactions in a feedback loop in the steady-state basal condition (17). These interactions involve Bcell secretion of insulin and its action on liver and peripheral tissues. The QUICKI is also defined by a formula applied to fasting insulin and glucose data, and the changes detected in this index are mostly related to insulin sensitivity estimated by the hyperinsulinemic euglycemic clamp in the whole body (19). The forearm studies specifically analyze the action of insulin on peripheral tissues, particularly muscle tissue (30). The significant correlation between the forearm studies data, involving mainly insulin sensitivity in muscle tissue, and the HOMA and QUICKI estimates of insulin sensitivity in the whole body indicated that in the pathological situations included in our study IR was present in muscle and probably in other metabolically active tissue such as hepatic and adipose tissue. Unfortunately, at present there are no well-defined cut-off points for HOMA or QUICKI that would permit the use of better statistical analysis such as kappa statistics for the analysis of the data.

\section{Acknowledgments}

The authors are grateful to Mario J.A. Saad, Walkyria P. Pimenta, Gloria M.G.F. Paccola, Francisco J.A. Paula, Leonor M.B. Gouveia, Maria Teresa C.G. Torquato, Fernanda O.M. Menezes, Renan M. Montenegro Jr., and C.E. Piccinato for assistance in the forearm studies, and to Sebastião Brandão Filho for technical assistance.

\section{References}

1. Van Hoeften TW, Pimenta W, Mitrakou A, Korytkowski M, Jenssen T, Yki-Jarvinen H \& Gerich JE (2000). Relative contribution of beta cell function and tissue insulin sensitivity to fasting and postglucose-load glycemia. Metabolism, 49: 1319-1325.

2. De Fronzo RA (1988). The triumvirate: beta cell, muscle, liver. A collusion for NIDDM. Diabetes, 37: 667-687.

3. De Fronzo RA \& Ferrannini E (1991). Insulin resistance: a multifaceted syndrome responsible for NIDDM, obesity, hypertension, dys- lipidemia and atherosclerotic cardiovascular disease. Diabetes Care, 14: 173-194.

4. Taverna MJ (2002). Homeostatic model assessment (HOMA). Revista de la Asociación Latino Americana de Diabetes, X: 8-17.

5. Ferrannini E \& Mari A (1998). How to measure insulin sensitivity. Journal of Hypertension, 16: 895-906.

6. De Fronzo RA, Tobin JD \& Andres R (1979). Glucose clamp technique: a method for quantifying insulin secretion and resistance. 
American Journal of Physiology, 237: 214-236.

7. Bergman RN (1989). Lilly lecture. Toward physiological understanding of glucose tolerance. Minimal-model approach. Diabetes, 38: 1512-1527.

8. Bergman RN, Prager R, Volund A \& Olefesky JM (1987). Equivalence of the insulin sensitivity index in man derived by the minimal model method and the euglycemic glucose clamp. Journal of Clinical Investigation, 79: 790-800.

9. Saad MJA, Pimenta WP, Paccola GMGF, Piccinato CE, Moreira AC \& Foss MC (1989). Effect of glucose ingestion on peripheral glucose metabolism in normal man. Diabetes and Metabolism, 15: 5-10.

10. Foss MC, Paccola GMGF, Saad M, Pimenta W, Piccinato CE \& lazigi $N$ (1990). Peripheral glucose metabolism in human hyperthyroidism. Journal of Clinical Endocrinology and Metabolism, 70: 11671172.

11. Foss MC, Saad M, Paccola GMGF, Paula FJA, Piccinato CE \& Moreira AC (1991). Peripheral glucose metabolism in acromegaly. Journal of Clinical Endocrinology and Metabolism, 72: 1048-1053.

12. Foss MC, Saad MJA, Paccola GMGF, Paula FJA \& Piccinato CE (1992). Peripheral glucose metabolism in patients with insulin resistance and acanthosis nigricans. Hormone and Metabolic Research, 24: 26-30.

13. Paula FJA, Gouveia LMFB, Paccola GMGF, Piccinato CE, Moreira AC \& Foss MC (1994). Androgen-related effects on peripheral glucose metabolism in women with congenital adrenal hyperplasia. Hormone and Metabolic Research, 26: 552-556.

14. Gouveia LMFB, Moyses-Neto M, Paccola GMGF, Piccinato CE \& Foss MC (1995). Peripheral glucose metabolism in patients with chronic renal failure. Brazilian Journal of Medical and Biological Research, 28: 201-207.

15. Foss MC, Paula FJA, Paccola GMGF \& Piccinato CE (1995). Peripheral glucose metabolism in human hyperprolactinemia. Clinical Endocrinology, 43: 721-726.

16. Foss MC, Gouveia LMFB, Moyses-Neto M, Paccola GMGF \& Piccinato CE (1996). Effect of hemodialysis on peripheral glucose metabolism of patients with chronic renal failure. Nephron, 73: 4853.

17. Mathews DR, Horsker JP, Rudeniski AS, Naylor BA, Treacher DF \& Turner RC (1985). Homeostasis model assessment: insulin resistance and beta cell function from fasting plasma glucose and insulin concentrations in man. Diabetologia, 28: 412-419.

18. Bonora E, Targher G, Alberiche M, Bonadonna RC, Saggiani F,
Zenere MB, Monauni T \& Muggeo M (2000). Homeostasis model assessment closely mirrors the glucose clamp technique in the assessment of insulin sensitivity. Diabetes Care, 23: 57-63.

19. Katz A, Mambi SS, Mather K, Baron AD, Follmann DA, Sullivam G \& Quon MJ (2000). Quantitative insulin sensitivity check index: a simple, accurate method for assessing insulin sensitivity in humans. Journal of Clinical Endocrinology and Metabolism, 85: 24022410.

20. Hrebicek J, Janout V, Malincikova J, Horakova D \& Cizek L (2002). Detection of insulin resistance by simple quantitative insulin sensibility check index QUICKI for epidemiological assessment and prevention. Journal of Clinical Endocrinology and Metabolism, 87: 144147.

21. Katsuki A, Sumida Y, Gabazza EC et al. (2002). QUICKI is useful for following improvements in insulin sensitivity after therapy in patients with type 2 diabetes mellitus. Journal of Clinical Endocrinology and Metabolism, 87: 2906-2908.

22. Norton JA, Burt ME \& Brennan MF (1945). Capacitance plethysmography validation in an ex vivo human limb model. Journal of Surgical Research, 160: 127-129.

23. Somogyi N (1945). Determination of blood sugar. Journal of Biological Chemistry, 160: 69-73.

24. Van Slyke DD \& Neill JM (1924). The determination of gases in blood and other solutions by vacuum extraction and manometric measurements. Journal of Biological Chemistry, 61: 523-573.

25. Soeldner JS \& Slone D (1985). Critical variables in the radioimmunoassay of serum insulin using the double antibody technique. Diabetes, 14: 771-779.

26. Dillon RS (1965). Importance of the hematocrit in interpretation of blood sugar. Diabetes, 14: 672-674.

27. Lusck G (1924). Animal calorimetry. Analysis of the oxidation of mixtures of carbohydrate and fat. Journal of Biological Chemistry, 59: 41-42.

28. Stumvoll $H$, Mitrakou A, Pimenta $W$, Jensen $T$, Yki-Jarvinen $H$, van Haften T, Renn W \& Gerich J (2000). Use of the oral glucose tolerance test to assess insulin release and insulin sensitivity. Diabetes Care, 23: 295-301.

29. Shott S (1990). Statistics for Health Professionals. W.B. Saunders, Philadelphia, PA, USA.

30. Foss MC (1994). Peripheral glucose metabolism in healthy subjects and in endocrine diseases. Brazilian Journal of Medical and Biological Research, 27: 959-979. 